\title{
Effect of Leaf Extracts and Panchagavya Foliar Spray on Plant Characters, Yield and Resultant Seed Quality of Blackgram [Vigna mungo (L.) Hepper] cv. CO 6
}

\author{
J. Gunasekar ${ }^{1 *}$, K. Swetha Reddy ${ }^{2}$, G. Poovizhi Sindhu ${ }^{2}$, S. Anand ${ }^{1}$, \\ G. Kalaiyarasi ${ }^{1}$, M. Anbarasu ${ }^{1}$ and K. Dharmaraj ${ }^{1}$
}

${ }^{1}$ Department of Genetics and Plant Breeding, Faculty of Agriculture, Annamalai University, Annamalai Nagar, Chidambaram, Tamil Nadu-608002, India

${ }^{2}$ Department of Soil Science and Agricultural Chemistry, Faculty of Agriculture, Annamalai University, Annamalai Nagar, Chidambaram, Tamil Nadu-608002, India

*Corresponding author

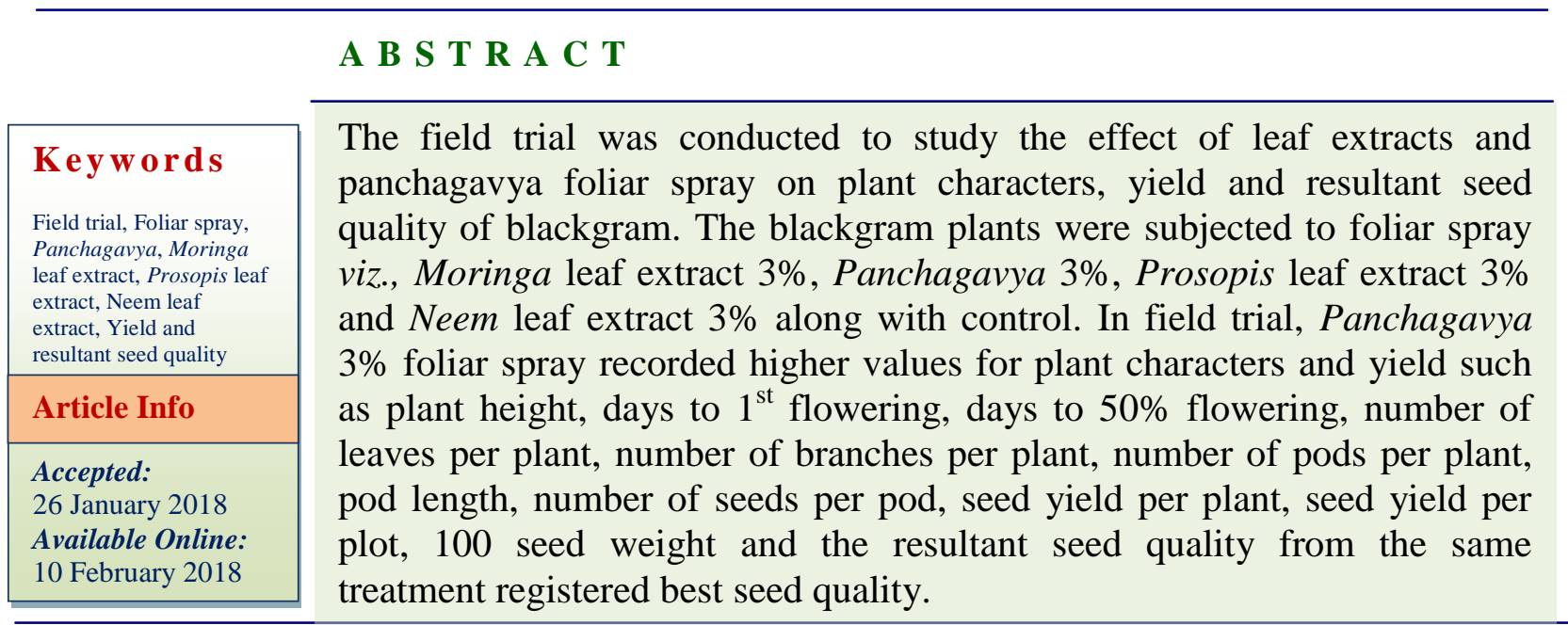

\section{Introduction}

Blackgram (Vigna mungo L.) also known as "Urad" one of the most important pulse crops grown all over India. It is also grown in tropics and sub tropic countries. It is mostly consumed as pulse and in the preparation of typical Indian dishes like pappad, idli, dosa and vada (Indira and Kurup, 2003). In India the blackgram production is estimated to achieve 2.89 lakh tonnes during the year (2016
- 2017) (Anon, 2017). Blackgram contains higher amount of protein (24-26\%) and is reported to be rich in Potassium (K), Phosphorus (P) and Calcium (Ca) with good amount of Sodium (Na) (Eswara Raghava Kumari et al., 2018). The potential of blackgram is very low due to various physiological, biochemical as well as inherent factors associated with the crops (Devaraju and Senthivel, 2018). The low productivity of blackgram was due to delayed monsoon, non- 
availability of high yielding varieties and low soil fertility. One among the best methods to overcome this situation is foliar spray. Foliar spray is a technique of feeding plants by applying liquid formulations directly to their leaves. Plants are able to absorb essential elements through their leaves. The absorption takes place through their stomata and also through their epidermis. Foliar spraying also stimulates nutrient uptaking from the soil.

Foliar spray reduces the loss of fertilizers through absorption, leaching or other process associated with soil application with normal moisture availability or normal soil condition. Foliar spray of nutrients using water soluble fertilizer is one of the possible ways to enhance the productivity of pulses like greengram and blackgram. Secondarily, foliar feeding can be effective management tool to favourably influence pre-reproductive growth stages by compensating for environmentally induced stresses of adverse growing conditions or poor nutrient availability. Early foliar applications can make an already good crop better, either by stimulating more vigourous regrowth or maximizing the yield potential growth stage period. In order to achieve the benefits of foliar feeding, combining proper methods of application and the best suited nutrient materials related to specific crops is essential.

\section{Materials and Methods}

A field trial was conducted at the Experimental Farm, Sevathur Village, Tiruppatthur Taluk, Vellore District, Tamil Nadu. The experiment was laid out in Randomized Block Design (RBD) and resultant seed quality was laid out in Completely Randomized Design (CRD) with four replications. The plot size was $4 \times 2.5 \mathrm{~m}^{2}$. The crop was raised with the spacing of $30 \times$ $10 \mathrm{~cm}$ apart from the regular recommended package of practices for blackgram following foliar spray treatments were given during flower initiation period.

\section{Foliar spray}

To get $3 \%$ concentration, 3 litre of solution was mixed with 100 litre of water and was applied using hand sprayer at 25, 35 and 45 days after sowing (DAS).

\section{Treatment details}

$\mathrm{T}_{0}-$ Control

$\mathrm{T}_{1}-$ Moringa leaf extract $3 \%$

$\mathrm{T}_{2}-$ Panchagavya 3\%

$\mathrm{T}_{3}-$ Prosopis leaf extract $3 \%$

$\mathrm{T}_{4}-$ Neem leaf extract $3 \%$

Experiment was carried out to study the effect of leaf extracts and panchagavya foliar spray on plant characters, yield and resultant seed quality of blackgram. Plant characters, yield and resultant seed quality viz., plant height, days to $1^{\text {st }}$ flowering, days to $50 \%$ flowering, number of leaves per plant, number of branches per plant, number of pods per plant, pod length, number of seeds per pod, seed yield per plant, seed yield per plot, 100 seed weight, germination (\%), speed of germination, shoot length, root length, seedling length, dry matter production, vigour index I and vigour index II were observed and recorded. The statistical data collected and analyzed by using ANOVA.

\section{Results and Discussion}

The field trial was conducted in blackgram variety cv. CO 6 to study the effect of leaf extracts and panchagavya foliar spray on plant characters, yield and resultant seed quality and the following observations were studied and the results are discussed below. Highly significant differences were recorded among the foliar spray treatments, Panchagavya 3\% $\left(\mathrm{T}_{2}\right)$ recorded the maximum height $(39.70 \mathrm{~cm})$ 
and was followed by Moringa leaf extract 3\% $\left(\mathrm{T}_{1}\right)(38.70 \mathrm{~cm})$ and the untreated plant $\left(\mathrm{T}_{0}\right)$ recorded the minimum plant height (31.20 $\mathrm{cm})$.Application of panchagavya $3 \%$ as foliar spray increased the plant height by $27.24 \%$ over the control. Increased plant height may be due to increase in protein synthesis and growth regulators such as IAA and $\mathrm{GA}_{3}$, in panchagavya may enhanced the cell division, cell multiplication and cell enlargement which favours increased inter nodal length (Sanjutha et al., 2008) experienced by Natarajan (2002) in vegetables and legumes. The lower plant height was observed in control may be due to inadequate nutrient supply during the crop growth stages (Rajendran, 1991). Chemotrophs and autotropic (ammonifiers and nutrifiers) present in panchagavya which colonize in the leaves increase the ammonia uptake and enhance total nitrogen supply and thereby increase the plant height and vegetative growth (Xu, 2001; Sharmila and Saravanan, 2012). The plant growth substance in panchagavya helps to bring rapid changes in phenotypes of plants by enhancing cell division and elongation and also improves the growth and productivity (Yadav and Lourdraj, 2006; Kondapa et al., 2009; Venkataramana et al., 2009 and Tharmaraj et al., 2011) and may also due to the steady supply of essential plant nutrients to crop, availability of moisture, favourable soil physical environment and the highest level of primary nutrients which prompted the auxillary buds into new shoots (Sanjutha et al., 2008). Days to $1^{\text {st }}$ flowering was maximum in $\left(\mathrm{T}_{0}\right)$ (32.78 days) and the minimum days to $1^{\text {st }}$ flowering was recorded in the treatment $\left(\mathrm{T}_{2}\right)$ (30.52 days) when compared to the other treatments. Days to $50 \%$ flowering was maximum in $\left(\mathrm{T}_{0}\right)(40.23$ days) and the minimum days to $50 \%$ flowering was recorded in the treatment $\left(\mathrm{T}_{2}\right)$ (36.52 days) when compared to the other treatments. The days to $1^{\text {st }}$ flowering (30.52 days after sowing) and days to $50 \%$ flowering (36.52 days after sowing) earlier in panchagavya sprayed plants. This may be due to supply of all micro and macronutrients and growth enzymes present in the panchagavya which favoured rapid cell division and multiplication. The probable reason for early flowering in case of panchagavya sprayed plants $\left(\mathrm{T}_{2}\right)$ may be due to the earlier and quicker emergence of seedlings and also due to the presence of growth promoting substances like IAA, $\mathrm{GA}_{3}$ and cytokinin and other mineral nutrients which favours translocation of more photo-assimilates to reproductive parts thereby induces early flowering. These findings are in confirmation with Ramaswamy and Vijaykumar (2009). Highly significant differences were recorded among the foliar spray treatments, Panchagavya 3\% $\left(\mathrm{T}_{2}\right)$ recorded maximum number of leaves per plant (16.00) and was followed by Moringa leaf extract $3 \%\left(\mathrm{~T}_{1}\right)$ (15.00) and the untreated plant $\left(\mathrm{T}_{0}\right)$ recorded the minimum number of leaves (12.00).Highly significant differences were recorded among the foliar spray treatments, Panchagavya 3\% $\left(\mathrm{T}_{2}\right)$ recorded the maximum number of branches per plant (3.90) and was followed by Moringa leaf extract $3 \%\left(\mathrm{~T}_{1}\right)(3.10)$ and the untreated plant $\left(\mathrm{T}_{0}\right)$ recorded the minimum number of branches per plant (2.60).More number of leaves per plant to the tune of $33.33 \%$ increase in number of leaves per plant and $50.00 \%$ increase in number of branches per plantwas recorded by $\mathrm{T}_{2}$ over the control $\left(\mathrm{T}_{0}\right)$ which may be due to the growth enzymes present in panchagavya (Patil et al., 2012) and microbes which increased the availability of more nutrients, moisture and improvement of soil environment that leads to more crop growth and development. Among the foliar spray treatments, Panchagavya $3 \% \quad\left(\mathrm{~T}_{2}\right)$ recorded the maximum number of pods per plant (26.00) and was followed by Moringa leaf extract 3\% $\left(\mathrm{T}_{1}\right)(25.00)$ and the untreated plant $\left(\mathrm{T}_{0}\right)$ recorded the minimum number of pods per plant (22.00). Among the foliar spray treatments, Panchgavya3\% $\left(\mathrm{T}_{2}\right)$ recorded the 
highest pod length $(5.40 \mathrm{~cm})$ and was followed by Moringa leaf extract 3\% ( $\left.\mathrm{T}_{1}\right)$ $(5.10 \mathrm{~cm})$ and the untreated plant $\left(\mathrm{T}_{0}\right)$ recorded the lowest pod length $(4.30 \mathrm{~cm})$. Among the foliar spray treatments, Panchagavya 3\% $\left(\mathrm{T}_{2}\right)$ recorded the higher number of seeds per pod (6.00) and was followed by Moringa leaf extract 3\% ( $\left.\mathrm{T}_{1}\right)$ (5.00) and the untreated plant $\left(\mathrm{T}_{0}\right)$ recorded the lower number of seeds per pod (4.00).Higher number of pods per plant and $18.18 \%$ increase in number of pods per plant recorded by $T_{2}$ over the control $\left(T_{0}\right)$ which may be due to the accumulation of cytokinin and auxin in their auxiliary buds have favoured the plants to produce more number of pods per plant (Vennila and Jayanthi, 2008). The significant improvement in the accumulation of dry matter, chlorophyll content and enhancement in the biological efficiency of crop plants results in improved yield and yield attributing characters (Natarajan, 2002).Nearly $25.58 \%$ increase in pod length, and $50.00 \%$ increase in number of seeds per pod was recorded by $\mathrm{T}_{2}$ over the control $\left(\mathrm{T}_{0}\right)$. This increase may be due to the quantities of IAA and $\mathrm{GA}_{3}$ present in panchagavya when applied as foliar spray could have created stimuli in the plant system and increased the production of growth regulator in cell system and the action of growth regulators in plant system stimulated the necessary growth and development (Yadav and Lourdraj, 2006). Among the foliar spray treatments, Panchagavya 3\% $\left(\mathrm{T}_{2}\right)$ recorded the higher seed yield per plant (5.48 g) and was followed by Moringa leaf extract 3\% ( $\left.\mathrm{T}_{1}\right)$ $(5.30 \mathrm{~g})$ and the untreated plant $\left(\mathrm{T}_{0}\right)$ recorded the lower seed yield per plant (4.85 g).Among the foliar spray treatments, Panchagavya 3\% $\left(\mathrm{T}_{2}\right)$ recorded the highest seed yield per plot $(1.47 \mathrm{~kg})$ and was followed by Moringa leaf extract $3 \%\left(\mathrm{~T}_{1}\right)(1.45 \mathrm{~kg})$ and the untreated plant $\left(\mathrm{T}_{0}\right)$ recorded the lowest seed yield per plot $(1.26 \mathrm{~kg})$.Among the foliar spray treatments, Panchagavya 3\% $\left(\mathrm{T}_{2}\right)$ recorded the highest 100 seed weight $(6.10 \mathrm{~g})$ and was followed by Moringa leaf extract 3\% ( $\left.\mathrm{T}_{1}\right)$ $(6.00 \mathrm{~g})$ and the untreated plant $\left(\mathrm{T}_{0}\right)$ recorded the lowest 100 seed weight (5.00 g).Increment in 100 seed weight to the tune of $22.00 \%$ was recorded by $\mathrm{T}_{2}$ over the control $\left(\mathrm{T}_{0}\right)$. This increase may be due to the fact that cow dung in panchagavya acts as a medium for the growth of beneficial microbes and provides nitrogen which is essential for crop growth and results in more seed weight (De Britto and Girija, 2006). Almost $12.99 \%$ increase in seed yield per plant and $16.67 \%$ increase in seed yield per plot was recorded by $\mathrm{T}_{2}$ over the control $\left(\mathrm{T}_{0}\right)$. This may be due to the nutrients present in the panchagavya (i.e.) macronutrients like Nitrogen $(\mathrm{N})$, Phosphorus $(\mathrm{P})$, Potassium $(\mathrm{K})$ and micronutrients which are required for the growth and development of plants. Beside this, the presence of various amino acids, vitamins, growth regulators like Auxins, Gibberellins, Cytokinin and also beneficial microorganisms like pseudomonas, azatobacter and phosphobacteria which influenced yield attributing characters like number of pods per plant, number of seeds per pod and 100 seed weight increases the field stand (Ali et al., 2011). Increase in seed yield was mainly due to increase in number of seeds and 100 seed weight. This was in conformity with the findings of Kavipriya et al., (2011) in greengram. Abundant supply of nutrients might have increased the protoplasmic constituents and accelerate the process of cell division and elongation. This in turn resulted in increased yield. Yield increases in $\left(\mathrm{T}_{2}\right)$ may be due to the hormonal substances present in panchagavya especially cytokinin which plays a role in vegetative plant parts with nutrient partitioning while in reproductive parts, high levels of nutrient mobilization. Increase in yield may also be due to fact that cow dung in panchagavya act as a medium for the growth of beneficial microbes and cow urine provides nitrogen which is essential for crop growth (De Britto and Girija, 2006; Patil et al., 2012). 
Table.1 Effect of leaf extracts and panchagavya foliar spray on plant characters of Blackgram cv. CO 6

\begin{tabular}{|c|c|c|c|c|c|}
\hline $\begin{array}{c}\text { Treatment } \\
(\mathrm{T})\end{array}$ & $\begin{array}{c}\text { Plant } \\
\text { height } \\
(\mathbf{c m})\end{array}$ & $\begin{array}{c}\text { Days to } \mathbf{1}^{\text {st }} \\
\text { flowering }\end{array}$ & $\begin{array}{c}\text { Days to } \\
\mathbf{5 0 \%} \\
\text { flowering }\end{array}$ & $\begin{array}{c}\text { Number of } \\
\text { leaves per } \\
\text { plant }\end{array}$ & $\begin{array}{c}\text { Number of } \\
\text { branches } \\
\text { per plant }\end{array}$ \\
\hline $\mathrm{T}_{0}$ & 31.20 & 32.78 & 40.23 & 12.00 & 2.60 \\
\hline $\mathrm{T}_{1}$ & 38.70 & 31.26 & 37.04 & 15.00 & 3.10 \\
\hline $\mathrm{T}_{2}$ & 39.70 & 30.52 & 36.52 & 16.00 & 3.90 \\
\hline $\mathrm{T}_{3}$ & 36.50 & 32.28 & 38.27 & 13.00 & 2.80 \\
\hline $\mathrm{T}_{4}$ & 37.50 & 31.27 & 37.06 & 14.00 & 2.90 \\
\hline Mean & 36.72 & 31.62 & 37.82 & 14.00 & 3.06 \\
\hline SEd & 0.2291 & 0.2772 & 0.1818 & 0.2580 & 0.0258 \\
\hline CD $(\mathbf{P}=05)$ & 0.5292 & 0.6402 & 0.4199 & 0.5959 & 0.0596 \\
\hline
\end{tabular}

Table.2 Effect of leaf extracts and panchagavya foliar spray on yield of blackgram cv. CO 6

\begin{tabular}{|c|c|c|c|c|c|c|}
\hline $\begin{array}{c}\text { Treatment } \\
(\mathrm{T})\end{array}$ & $\begin{array}{c}\text { Number } \\
\text { of pods } \\
\text { per plant }\end{array}$ & $\begin{array}{c}\text { Pod length } \\
(\mathrm{cm})\end{array}$ & $\begin{array}{c}\text { Number } \\
\text { of seeds } \\
\text { per pod }\end{array}$ & $\begin{array}{c}\text { Seed yield } \\
\text { per plant } \\
(\mathrm{g})\end{array}$ & $\begin{array}{c}\text { Seed yield } \\
\text { per plot } \\
(\mathrm{kg})\end{array}$ & $\begin{array}{c}\text { 100 seed } \\
\text { weight }(\mathrm{g})\end{array}$ \\
\hline $\mathrm{T}_{0}$ & 22.00 & 4.30 & 4.00 & 4.85 & 1.26 & 5.00 \\
\hline $\mathrm{T}_{1}$ & 25.00 & 5.10 & 5.00 & 5.30 & 1.45 & 6.00 \\
\hline $\mathrm{T}_{2}$ & 26.00 & 5.40 & 6.00 & 5.48 & 1.47 & 6.10 \\
\hline $\mathrm{T}_{3}$ & 23.00 & 4.70 & 4.00 & 4.98 & 1.36 & 5.20 \\
\hline $\mathrm{T}_{4}$ & 24.00 & 4.90 & 5.00 & 5.32 & 1.38 & 5.50 \\
\hline $\mathrm{Mean}$ & 24.00 & 4.88 & 4.80 & 5.18 & 1.38 & 5.56 \\
\hline $\mathrm{SEd}$ & 0.1842 & 0.0491 & 0.2456 & 0.0573 & 0.0045 & 0.0167 \\
\hline $\mathrm{CD}(\mathrm{P}=\mathbf{0 5})$ & 0.4254 & 0.1135 & 0.5674 & 0.1323 & 0.0103 & 0.0387 \\
\hline
\end{tabular}

Table.3 Effect of leaf extracts and panchagavya foliar spray on resultant seedling charactersof blackgram cv. CO 6

\begin{tabular}{|c|c|c|c|c|}
\hline Treatment $(\mathrm{T})$ & $\begin{array}{c}\text { Germination } \\
(\%)\end{array}$ & $\begin{array}{c}\text { Speed of } \\
\text { germination }\end{array}$ & $\begin{array}{c}\text { Shoot length } \\
(\mathbf{c m})\end{array}$ & $\begin{array}{c}\text { Root length } \\
(\mathbf{c m})\end{array}$ \\
\hline $\mathrm{T}_{0}$ & $87.00(68.86)$ & 20.30 & 16.50 & 15.60 \\
\hline $\mathrm{T}_{1}$ & $92.00(73.57)$ & 24.00 & 18.70 & 16.20 \\
\hline $\mathrm{T}_{2}$ & $93.00(74.66)$ & 26.50 & 19.50 & 17.30 \\
\hline $\mathrm{T}_{3}$ & $90.00(71.56)$ & 22.00 & 17.30 & 16.40 \\
\hline $\mathrm{T}_{4}$ & $91.00(72.54)$ & 23.50 & 18.40 & 17.20 \\
\hline Mean & $90.60(72.24)$ & 23.26 & 18.08 & 16.54 \\
\hline SEd & $0.1923(0.1835)$ & 0.5022 & 0.2202 & 0.1343 \\
\hline $\mathrm{CD}(\mathrm{P}=05)$ & $0.4287(0.4093)$ & 1.1200 & 0.4909 & 0.1899 \\
\hline
\end{tabular}

(Figures in parenthesis indicate arcsine transformed value) 
Table.4 Effect of leaf extracts and panchagavya foliar spray on resultant seedling length $(\mathrm{cm})$, dry matter production ( $\mathrm{g}$ seedling ${ }^{-10}$ ), vigour index I and vigour index II of blackgram cv. CO 6

\begin{tabular}{|c|c|c|c|c|}
\hline $\begin{array}{c}\text { Treatment } \\
(\mathrm{T})\end{array}$ & $\begin{array}{c}\text { Seedling } \\
\text { length }(\mathbf{c m})\end{array}$ & $\begin{array}{c}\text { Dry matter } \\
\text { production }(\mathrm{g} \\
\text { seedling }\end{array}$ & $\begin{array}{c}\text { Vigour index } \\
\text { I }\end{array}$ & $\begin{array}{c}\text { Vigour index } \\
\text { II }\end{array}$ \\
\hline $\mathrm{T}_{0}$ & 32.10 & 0.1160 & 2792.70 & 10.09 \\
\hline $\mathrm{T}_{1}$ & 34.90 & 0.1250 & 3210.80 & 11.50 \\
\hline $\mathrm{T}_{2}$ & 36.80 & 0.1320 & 3422.40 & 12.27 \\
\hline $\mathrm{T}_{3}$ & 33.70 & 0.1170 & 3033.00 & 10.53 \\
\hline $\mathrm{T}_{4}$ & 35.60 & 0.1220 & 3239.70 & 11.10 \\
\hline $\mathrm{Mean}$ & 34.62 & 0.1224 & 3139.70 & 11.10 \\
\hline $\mathrm{SEd}$ & 0.7065 & 0.0012 & 9.4866 & 0.1669 \\
\hline $\mathrm{CD}(\mathbf{P = 0 5})$ & 1.5755 & 0.0026 & 21.1551 & 0.3723 \\
\hline
\end{tabular}

Fig.1 Effect of leaf extracts and panchagavya foliar spray on number of pods per plant and number of seeds per pod of blackgram cv. CO 6

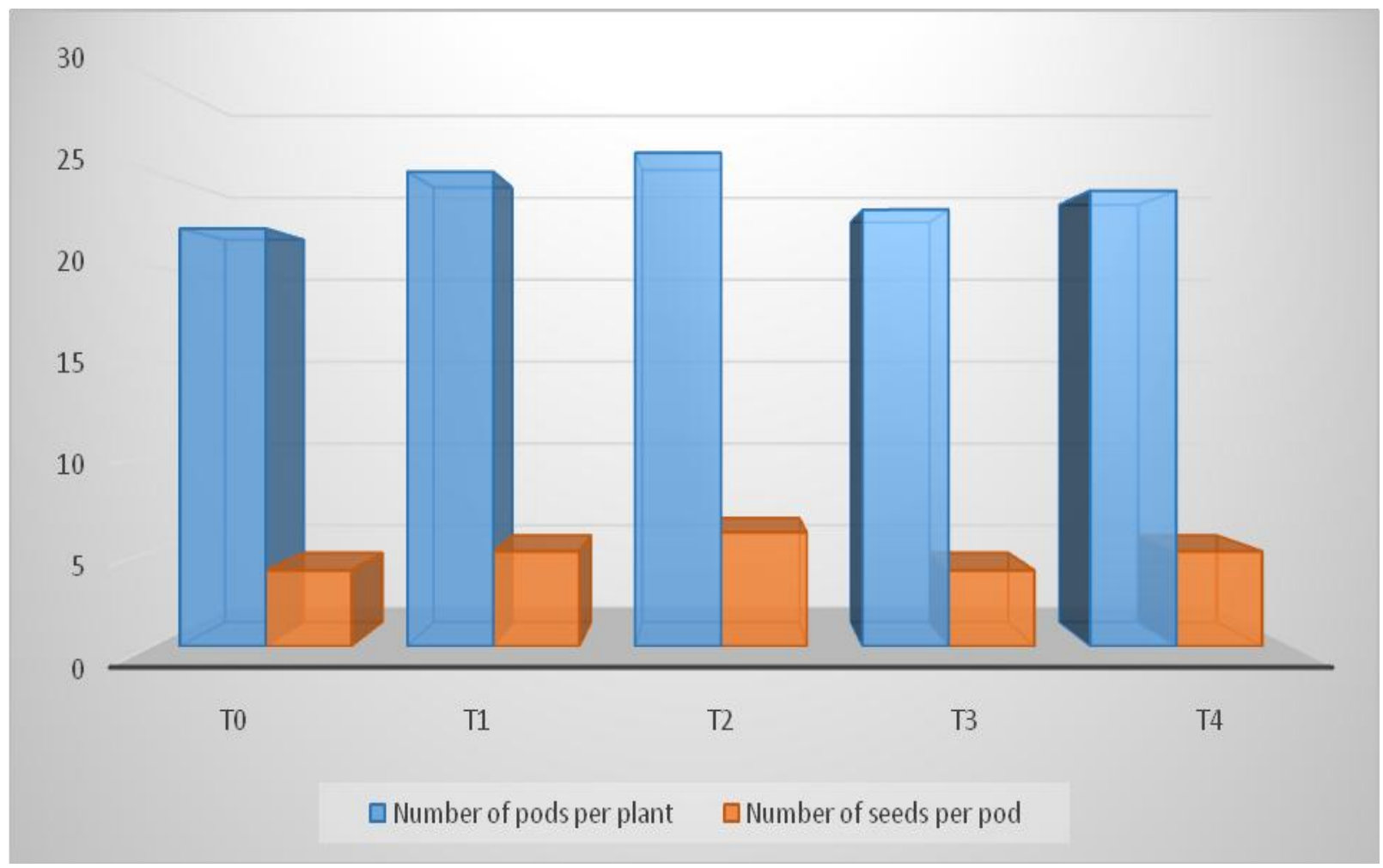


Fig.2 Effect of leaf extracts and panchagavya foliar spray on seed yield per plant and 100 seed weight of blackgram cv. CO 6

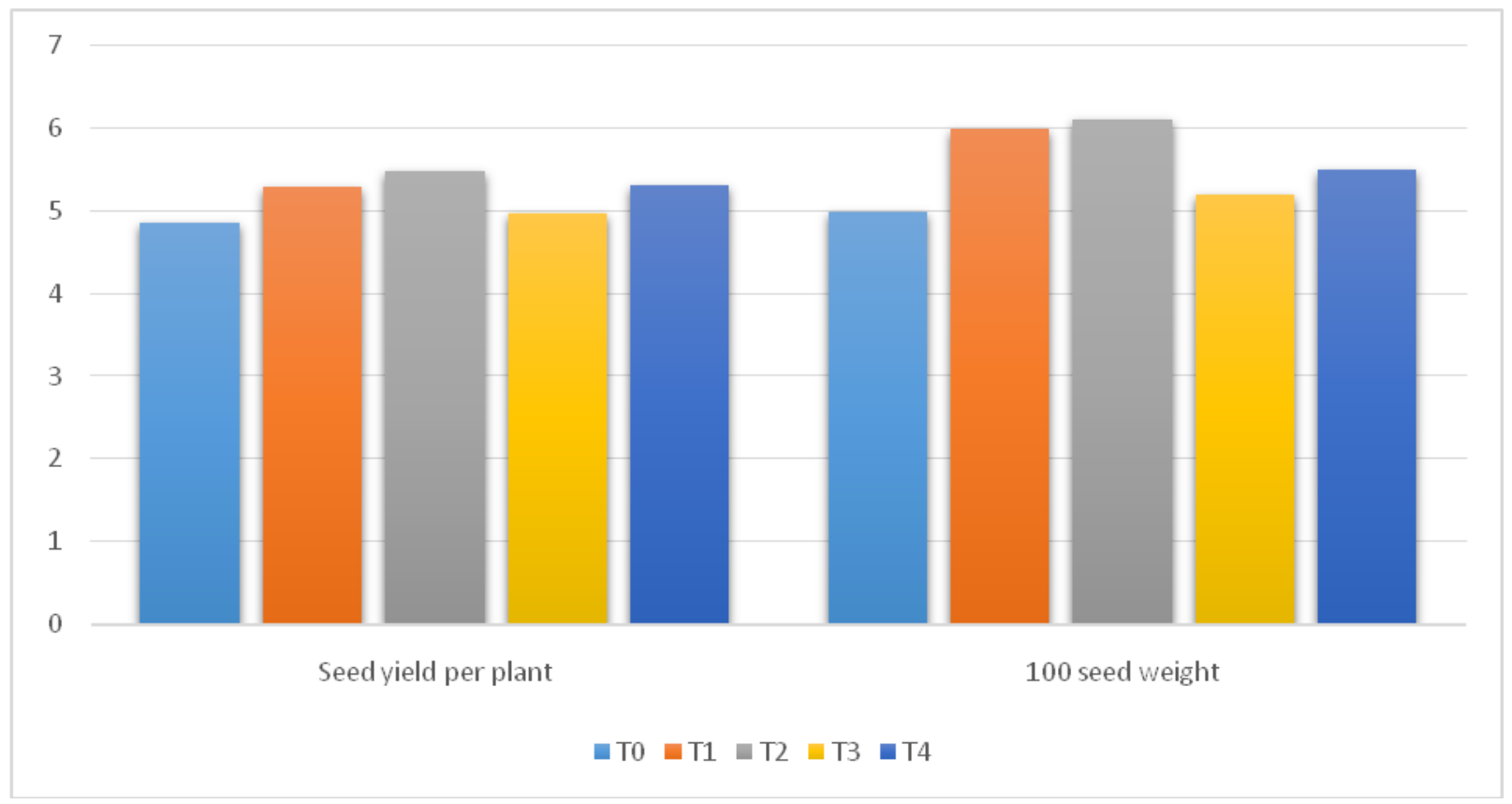

Fig.3 Effect of leaf extracts and panchagavya foliar spray on germination (\%) of resultant seed of blackgram cv. $\mathrm{CO} 6$

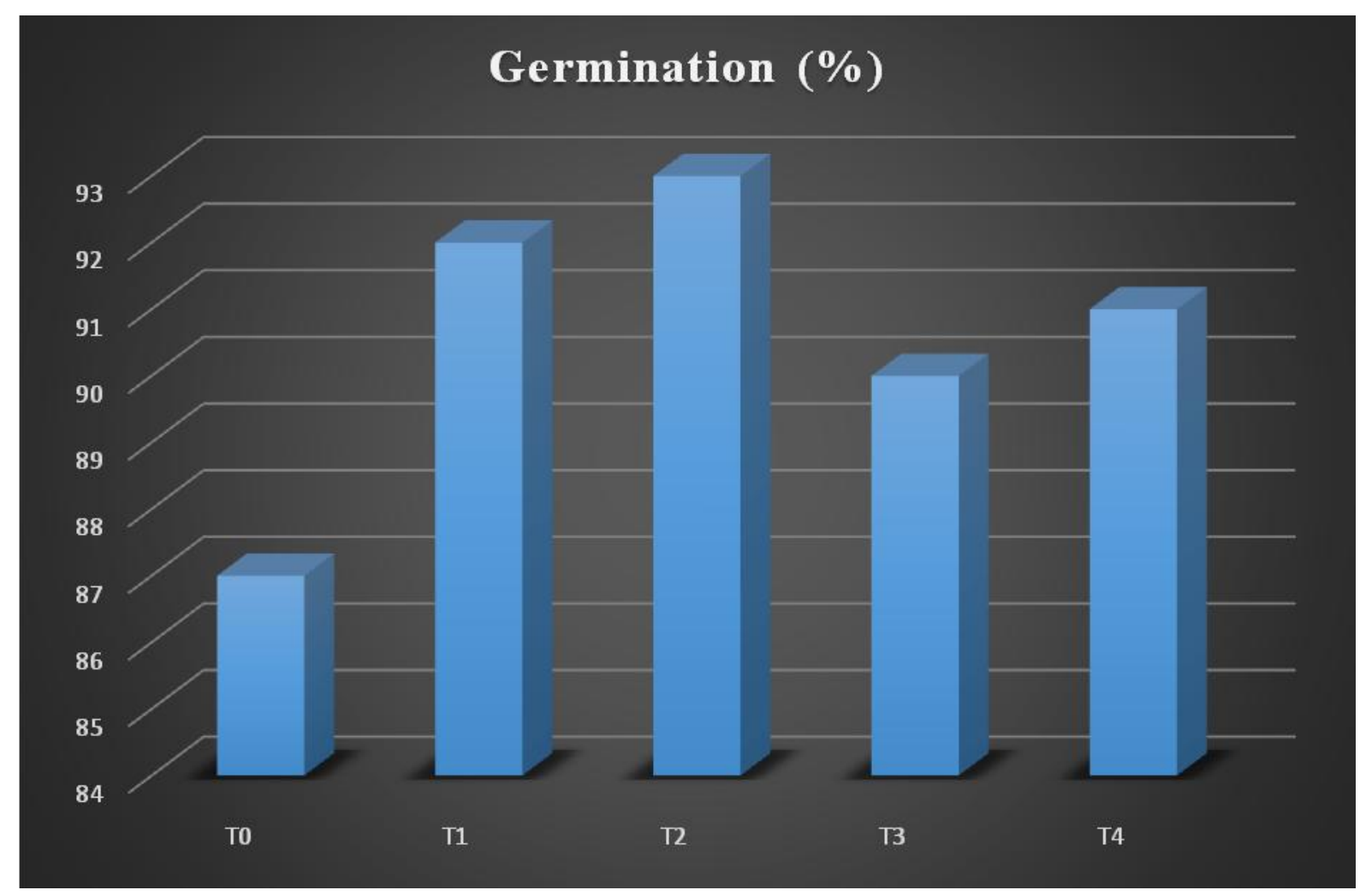


This was in conformity with the works of (Somasundaram et al., 2007; Tharmaraj et al., 2011; Ravikumar et al., 2012; Yadav Prakash and Tripathi, 2013). The least yield in control might be due to the lack of adequate supply of phosphate and nitrogen to the crop which in turn affected the growth and yield components of the crop (reduction in source and sink) ultimately reflecting on yield. Similar results were reported by (Pandian et al., 2001; Kumar et al., 2011). Among the foliar spray treatments,Panchagavya 3\% $\left(\mathrm{T}_{2}\right)$ recorded the highest germination percentage $(93.00 \%)$ and was followed by Moringa leaf extract $3 \%\left(\mathrm{~T}_{1}\right)(92.00 \%)$ and seeds from the untreated plant $\left(\mathrm{T}_{0}\right)$ recorded the lowest germination percentage $(87.00 \%)$. Among the foliar spray treatments, Panchagavya $3 \%$ $\left(\mathrm{T}_{2}\right)$ recorded the maximum speed of germination (26.50) and was followed by Moringa leaf extract 3\% ( $\left.\mathrm{T}_{1}\right)(24.00)$ and seeds from the untreated plant $\left(\mathrm{T}_{0}\right)$ recorded the slowest speed of germination (20.30).Among the foliar spray treatments, Panchagavya 3\% $\left(\mathrm{T}_{2}\right)$ recorded the highest shoot length $(19.50 \mathrm{~cm})$ and was followed by Moringa leaf extract 3\% $\left(\mathrm{T}_{1}\right)(18.70 \mathrm{~cm})$ and seeds from the untreated plant $\left(\mathrm{T}_{0}\right)$ recorded the lowest shoot length $(16.50 \mathrm{~cm})$. Among the foliar spray treatments, Panchagavya 3\% $\left(\mathrm{T}_{2}\right)$ recorded the highest root length (17.30 $\mathrm{cm})$ and was followed by Moringa leaf extract $3 \%\left(\mathrm{~T}_{1}\right)(16.20 \mathrm{~cm})$ and seeds from the untreated plant $\left(\mathrm{T}_{0}\right)$ recorded the lowest root length $(15.60 \mathrm{~cm})$. Among the foliar spray treatments, Panchagavya $3 \%\left(\mathrm{~T}_{2}\right)$ recorded the highest seedling length $(36.80 \mathrm{~cm})$ and was followed by Moringa leaf extract 3\% $\left(\mathrm{T}_{1}\right)$ $(34.90 \mathrm{~cm})$ and seeds from the untreated plant $\left(\mathrm{T}_{0}\right)$ recorded the lowest seedling length $(32.10 \mathrm{~cm})$. Among the foliar spray treatments, Panchagavya $3 \%\left(\mathrm{~T}_{2}\right)$ recorded the highest dry matter production $(0.1320 \mathrm{~g})$ and was followed by Moringa leaf extract 3\% $\left(\mathrm{T}_{1}\right)(0.1250 \mathrm{~g})$ and seeds from the untreated plant $\left(\mathrm{T}_{0}\right)$ recorded the lowest dry matter production $(0.1160 \mathrm{~g})$. Maximum vigour index I values was recorded by foliar spray with Panchagavya 3\% ( $\left.\mathrm{T}_{2}\right)$ (3422.40) and was followed by Moringa leaf extract $3 \%\left(\mathrm{~T}_{1}\right)$ (3210.80) and seeds from the untreated plant $\left(\mathrm{T}_{0}\right)$ recorded the minimum number of vigour index I (2792.70). Maximum vigour index II values was recorded by foliar spray with Panchagavya 3\% $\left(\mathrm{T}_{2}\right) \quad(12.27)$ and was followed by Moringa leaf extract 3\% ( $\left.\mathrm{T}_{1}\right)$ (11.50) and seeds from the untreated plant $\left(\mathrm{T}_{0}\right)$ recorded the minimum number of vigour index II (10.09). In the present foliar spray, panchagavya 3\% $\left(\mathrm{T}_{2}\right)$ applied plants recorded higher values for resultant seed qualities viz., germination percentage $(93.00 \%)$, speed of germination $(26.50)$, root length $(17.30 \mathrm{~cm})$, shoot length $(19.50 \mathrm{~cm})$, seedling length $(36.80 \mathrm{~cm})$, dry matter production $(0.1320 \mathrm{~g}$ seedling $\left.{ }^{-10}\right)$, vigour index I (3422.40) and vigour index II (12.27) and control $\left(\mathrm{T}_{0}\right)$ recorded the lower values. This increase was due to supply of all micro and macronutrients present in the panchagavya and also by the growth enzymes present in panchagavya favoured rapid cell division and multiplication as reported by Ramaswamy and Vijaykumar (2009). Improved nutrition may enable greater leaf area production that results in greater interception of light thereby increasing dry matter production (source to sink) (Kumawat et al., 2009). The significant improvement and distribution of dry matter production in different parts was attributed to increased supply of plant nutrients, chlorophyll synthesis, nitrogen metabolism and phyto hormones with the foliar spray of panchagavya (Figs. 1-3; Table 1-4).

The present study on effect of leaf extracts and panchagavya foliar spray on plant characters, yield and resultant seed quality of blackgram concludes that the foliar spray of panchagavya 3\% increases the plant characters, yield attributes and resultant seed qualities. This increase was due to the 
presence of plant growth substance, growth enzymes, cow dung in panchagavya acts as a medium for the growth of beneficial microbes, nutrients present in panchagavya and presence of various amino acids, vitamins and growth regulators. Hence foliar spray of panchagavya 3\%which suits for increasing the plant characters, yield and resultant seed qualities of blackgram.

\section{References}

Ali, M.N., Ghatak, S. and Ragul, T. 2011. Biochemical analysis of panchagavya and Sanjibani and their effect in crop yield and soil health. J. Crop and Weed, 7: 84-86.

Anonymous. 2017. http://www.indiastat.com.

De Britto, J.A. and Girija, S.L. 2006. Investigation on the effect of organic and inorganic farming methods on blackgram and greengram. Indian $J$. Agric. Res., 40(3): 204-207.

Devaraju, B. and Senthivel, T. 2018. Effect of foliar application of different sources of nutrients on growth and yield of blackgram under irrigated conditions. Int. J. Curr. Microbiol. App. Sci., 7(1): 3105-3109.

Eswara Raghava Kumari, M., Vijaya Gopal, A. and Lakshmipathy, R. 2018. Effect of stress tolerant plant growth promoting rhizobacteria on growth of blackgram under stress condition. Int. J. Curr. Microbiol. App. Sci., 7(1): 14791487.

Indira, M. and Kurup, P.A. 2003. Black gram (Vigna mungo) - A hypolipidemic pulse. Nat. Prod. Radiance, 2(5): 240242.

Kavipriya, R., Dhanalakshmi, P.K., Jayashree, S. and Thangaraju, N. 2011.

Seaweed extract as a biostimulant for legume crop and greengram. J. Eco. Biotech., 3(8): 16-19.

Kondapa, D., Radder, B.M., Patil, P.L.,
Hebsur, N.S. and Alagundagi, S.C. 2009. Effect of integrated nutrient management on growth, yield and economics of chilli (cv. Byadgidabbi) in a vertisol. Karnataka J. Agric. Sci., 22(2): 438-440.

Kumar, R.S., Ganesh, P., Tharmaraj, K. and Saranraj, P. 2011. Growth and development of blackgram (Vigna mungo) under foliar application of panchagavya as organic source of nutrient. Curr. Bot., 2: 9-11.

Kumawat, R.N., Mahajan, S.S. and Mertia, R.S. 2009. Growth and development of groundnut (Arachis hypogaea) under foliar application of panchagavya and leaf extracts of endemic plant. Indian J. Agron., 54(3): 324-331.

Natarajan, K. 2002. Training workshop on indigenous knowledge. Ethnoveterinary practices and sustainable agriculture, Nam Valivelanmai, 6: 28-32.

Pandian, B.J., Anandkumar, S., Veerabadran, V. and Ravichandran, V.K. 2001. Growth and yield of rice fallow greengram as influenced by method of sowing, stubble management and nutrient application in Tambiraparani command area. Madras Agric. J., 88: 406-409.

Patil, S.V., Halikatti, S.I., Hiremath, S.M., Babalad, H.B., Sreenivasa, M.N., Hebsur, N.S. and Somanagouda, G. 2012. Effect of organics on growth and yield of chickpea (Cicer arietinum L.) in vertisols. Karnataka J. Agric. Sci., 25(3): 326-331.

Rajendran, R. 1991. Response of greengram (CO 4) to soil and foliar nutrition. Madras Agric. J., 78(9-12): 453-455.

Ramaswamy, V. and Vijaykumar, A. 2009. Effect of organic foliar application on seed yield and quality in senna. Seed Res., 37(1\&2): 48-52.

Ravikumar, M., Venkatesh, J., Niranjana, K.S. and Gurumurthy, B.R. 2012. Effect 
of nitrogen fixing bacteria in combination with organic manures and fertilizers on dry matter production and uptake of $\mathrm{N}, \mathrm{P}$ and $\mathrm{K}$ in Coleus forskohili. Green farming, 3(6): 637641.

Sanjutha, S., Subramanian, S., Rani, I. and Maheswari. 2008. Integrated nutrient management in Andrographispaniculata. Res. J. Agric. Biol. Sci., 4(2): 141-145.

Sharmila, D. and Saravanan, S. 2012. Efficacy of lead on germination growth \& morphological studies of Horsegram (Dolichosbiflorus Linn.). J. Chem. Pharm. Res., 4(11): 4894-4896.

Somasundaram, E., Sankaran, N., Meena, S., Thiyagarajan, T.M., Chandragiri, K. and Pannerselvam, S. 2007. Response of greengram to varied levels of panchagavya (organic nutrition) foliar spray. Madras Agric. J., 90(1-3): 169172.

Tharmaraj, K., Ganesh, P., Sureshkumar, R., Anandan, A. and Kolanjinathan, K. 2011. A critical review on panchagavya - A boon plant growth. Int. J. Pharm. Biol. Arch., 2(6): 1611-1614.
Venkataramana, P., Narasimha, M.B., Krishna, Rao, J.V. and Kamble, C.K. 2009. Studies on the integrated effect of organic manures and panchagavya foliar spray on mulberry (Morusalba L.) production and leaf quality evaluation through silkworm (Bombyx mori L.) rearing. Crop Res., 37(1, 2 \& 3): 282289.

Vennila, C. and Jayanthi, C. 2008. Response of okra to integrated nutrient management. J. Soils Crops, 18: 36-40.

$\mathrm{Xu}$, H.L. 2001. Effects of a microbial inoculant and organic fertilizers on the growth, photosynthesis and yield of sweet corn. J. Crop Prod., 3: 183-214.

Yadav Prakash and Tripathi, A.K. 2013. Growth and yield of greengram (Vigna radiata L.) under foliar application of panchagavya and leaf extracts of endemic plants. Indian J. Agron., 58: 618-621.

Yadav, B.K. and Lourdraj, A.C. 2006. Effect of organic manures and panchagavya spray on yield attributes, yield and economics of rice (Oryza sativa L.). Crop Res., 31(1): 1-5.

\section{How to cite this article:}

Gunasekar, J., K. Swetha Reddy, G. Poovizhi Sindhu, S. Anand, G. Kalaiyarasi, M. Anbarasu and Dharmaraj, K. 2018. Effect of Leaf Extracts and Panchagavya Foliar Spray on Plant Characters, Yield and Resultant Seed Quality of Blackgram [Vigna mungo (L.) Hepper] cv. CO 6. Int.J.Curr.Microbiol.App.Sci. 7(02): 3205-3214. doi: https://doi.org/10.20546/ijcmas.2018.702.385 